\title{
Anastrozole/Leuprolide Regimen
}

National Cancer Institute

\section{Source}

National Cancer Institute. Anastrozole/Leuprolide Regimen. NCI Thesaurus. Code C160532.

A regimen consisting of anastrozole and leuprolide that may be used in the treatment of certain hormone receptor (HR)-positive breast cancers. 